\title{
Access to Pharmaceutical Patents in the COVID-19 Emergency: A Case for Government Use in Nigeria
}

\author{
Adebambo Adewopo* \\ Nigerian Institute of Advanced Legal Studies, Abuja, Nigeria \\ tonade@yahoo.com
}

\begin{abstract}
The COVID-19 pandemic has continued to exert enormous pressure on public health policies and systems, with far-reaching implications. The race for vaccines has raised important intellectual property rights issues. These are evident in the need to advance the public interest and in the obligation of governments to address the challenge of access to vaccines, especially in sub-Saharan countries like Nigeria with relatively underdeveloped healthcare and innovation ecosystems. While the Nigerian Patents and Designs Act (PDA) establishes a compulsory licence regime that affords access to patented drugs, existing public healthcare is severely challenged in providing access to new medicines. This article examines the framework for patent protection of pharmaceuticals designed to meet public health challenges, such as those presented by the pandemic. It recommends the implementation of a government use provision under the PDA, with a view to addressing the challenge of access to COVID-19 vaccines.
\end{abstract}

\section{Keywords}

Pharmaceutical patent, public health, COVID-19 vaccines, compulsory licence, government use, Patents and Designs Act

Research professor, Nigerian Institute of Advanced Legal Studies; senior advocate of Nigeria. This article is a revised version of an original paper written in April 2020: AA Adewopo "Intellectual property rights, pharmaceutical patents and public health: Adopting compulsory and government use licenses in the COVID-19 emergency in Nigeria" (April 2020) Social Science Research Network, available at: <https://ssrn.com/abs tract=3580179> (last accessed 19 August 2021). Since then, both global and national statistics have changed rapidly; there has been significant success in the development of COVID-19 vaccines and several have been approved and listed by the World Health Organization for emergency use. See "Is there a vaccine for COVID-19?", available at: $<$ https://www.who.int/news-room/q-a-detail/coronavirus-disease-(covid-19)-vaccines?ad groupsurvey= $\{$ adgroupsurvey $\}$ \&gclid=EAIaIQobChMI7_b8jdDC8gIVisLtCh2ZKgw-EAAYA SAAEgJQVPD_BwE> (last accessed 19 August 2021). However, the issues of access and intellectual property rights remain. The core thesis of this article is the practical utility of a compulsory licence regime for facilitating access to COVID-19 vaccines in helping to support public health, particularly in emergencies, and this remains both relevant and valid particularly for sub-Saharan countries. 


\section{INTRODUCTION}

As the novel coronavirus (COVID-19) pandemic has rapidly evolved, policy makers and leaders have continued to grapple with one of the world's most grave public health crises. Within weeks of the outbreak starting in Wuhan, China in December 2019, the sheer gravity of both human and material cost, propelled by the rapidity of transmission with the attended death rate across many countries, was increasing exponentially. ${ }^{1}$ By the time the World Health Organization (WHO) declared the virus a pandemic, it had reached at least 114 countries. $^{2}$ As at late April 2020, when this article was originally written, the WHO had reported over 3 million confirmed cases and over 200,000 deaths globally, with numbers increasing (including many more unreported cases) and defying efforts to flatten the curve. ${ }^{3}$ By 21 June 2020, two months later, over 8 million cases and over 460,000 deaths had been recorded globally, ${ }^{4}$ while countries in Africa grappled with 224,673 cases and 4,996 deaths. ${ }^{5}$ Although relatively lower than that in other regions, the rate of infection in Africa portends grave danger for a region with a large number of fragile health systems and a vast population second only to that of China. ${ }^{6}$ Across countries and regions, increased transmission and new variants have continued to occur in the trajectory of the pandemic. In Nigeria, although with relatively lower country level epidemic trajectories, the total number of confirmed cases had risen to 20,244 with 518 reported deaths as

1 See "Mortality analyses" (Johns Hopkins Coronavirus Resource Center), available at: <https://coronavirus.jhu.edu/data/mortality> (last accessed 19 August 2021). See also Nigeria Centre for Disease Control (NCDC) updates on the COVID-19 outbreak in Nigeria, available at: <https://ncdc.gov.ng/diseases/sitreps/?cat=14\&name=An\%20update\%20of\% 20COVID-19\%20outbreak\%20in\%20Nigeria> (last accessed 19 August 2021).

2 See “Coronavirus disease 2019 (COVID-19): Situation report 51" (11 March 2020, WHO), available at: <https://www.who.int/docs/default-source/coronaviruse/situation-reports /20200311-sitrep-51-covid-19.pdf> (last accessed 19 August 2021).

3 3,175,207 cases and 224,172 deaths were reported in the "Coronavirus disease (COVID-19): Situation report 102” (1 May 2020, WHO), available at: <https://apps.who.int/iris/bits tream/handle/10665/332055/nCoVsitrep01May2020-eng.pdf?sequence=1\&isAllowed=y> (last accessed 19 August 2021). In Nigeria, there were 1,932 confirmed cases as at 30 April 2020: “COVID-19 situation report: Situation report 62" (30 April 2020, NCDC), available at: <https://ncdc.gov.ng/diseases/sitreps/?cat=14\&name=An\%20update\%20of\%20COVID19\%20outbreak\%20in\%20Nigeria> (last accessed 19 August 2021).

4 See "Coronavirus disease (COVID-19): Situation report 153" (21 June 2020, WHO), available at: <https://www.who.int/docs/default-source/coronaviruse/situation-reports/20200621covid-19-sitrep-153.pdf?sfvrsn=c896464d_2> (last accessed 19 August 2021).

5 See "Coronavirus disease (COVID-19): Situation report 154" (22 June 2020, WHO), available at: <https://www.who.int/docs/default-source/coronaviruse/situation-reports/20200622covid-19-sitrep-154.pdf?sfvrsn=d0249d8d_2> (last accessed 19 August 2021).

6 WHO statistics show that the Americas had the highest figures of 4,370,519 cases and 221,771 deaths, while the Western Pacific region had the lowest with 205,911 cases and 7,329 deaths: ibid. 
at 21 June $2020^{7}$ and this more than doubled by 24 September, barely three months later. ${ }^{8}$ The landscape has continued to record rapid development with respect to both global transmission and vaccine development.

The pandemic has exacted enormous pressure on public health policies and systems, and has also raised far-reaching political, economic, social and technological questions and uncertainties regarding global welfare and the prospects for a solution. ${ }^{9}$ If the impact of COVID-19 has been severe in most of the best healthcare systems, one can only imagine the impact on countries that have been paying lip service to their health sectors. The WHO has indicated the start of a series of consultations and collaboration among scientists, pharmaceutical companies and national health regulatory authorities. ${ }^{10}$ Before the development of vaccines, the global anti-COVID-19 campaign, actively supported by corporate organizations, enterprises and brand owners, continued to make tremendous progress in efforts towards fostering containment and control measures by public health and medical institutions. ${ }^{11}$ Consequently, countries embarked not only on pushing the frontiers of research and development of COVID-19 vaccines that would ultimately stem the tide, but also on rethinking their political, legal and regulatory strategies and institutions for providing access to successful vaccines, once ready for the global market. As the saying goes, invention is the mother of necessity. As the advent of vaccines would signal a high-water mark in tackling COVID-19, issues of intellectual property rights (IPRs) arising from emerging bio-medical and technological innovations significantly shaped the rapidly evolving COVID-19 era.

7 See "COVID-19 situation report: Situation report 114" (21 June 2021, NCDC), available at: <https://ncdc.gov.ng/diseases/sitreps/?cat=14\&name=An\%20update\%20of\%20COVID-19\% 20outbreak\%20in\%20Nigeria> (last accessed 19 August 2021). On the same date, 436 new confirmed cases and 12 deaths had been reported in the previous 24 hours: ibid.

8 "Coronavirus - Nigeria: COVID-19 case update (24 September 2020)" africanews, available at: <https://www.africanews.com/2020/09/25/coronavirus-nigeria-covid-19-case-update24-september-2020/> (last accessed 19 August 2021): 57,849 total cases; 1,102 deaths and 49,098 discharged.

9 See the International Monetary Fund Policy Tracker summarizing the key economic responses governments are taking to limit the human and economic impact of the COVID-19 pandemic. The tracker covers 197 economies and is available at: <https:// www.imf.org/en/Topics/imf-and-covid19/Policy-Responses-to-COVID-19> (last accessed 19 August 2021).

10 See "Coronavirus disease: Situation report 102", above at note 3.

11 These efforts include the production and donation of critical items and personal protective equipment, such as hydroalcoholic gels, face masks and gloves, including diagnostics for health workers, first responders and patients, which has helped in addressing supply gaps and facilitated the containment and control of the disease. Some of the well-known measures adopted across many countries include testing, tracing, social distancing, isolation, quarantine and lockdowns. See "Interim recommendations on obligatory hand hygiene against transmission of COVID-19” (1 April 2020, WHO), available at: <https:// www.who.int/publications/m/item/interim-recommendations-on-obligatory-hand-hygieneagainst-transmission-of-covid-19> (last accessed 19 August 2021). 
Ultimately, the real test is in the characteristic preventive function that vaccines have been well known to deliver globally. More than other forms of medical treatment or therapies, vaccines have a long history in respect of epidemics. For centuries since Edward Jenner's first recorded human vaccine for smallpox in the 1790s, human beings have not only benefited from vaccination but have used vaccines to combat epidemics, including different types of plagues, measles, diphtheria, anthrax and, more recently, cholera, malaria, HIV/AIDs, tuberculosis (TB) and now COVID-19. ${ }^{12}$ The combination of affordability, stability, immunity, ease of administration and sustained protection as a biological preparation often marks vaccines as the preferable panacea against epidemics. ${ }^{13}$ Although other types of COVID-19 prevention and treatment measures have been rapidly promoted, the development of vaccines has been the major focus of the global community and pharmaceutical industry in the fight against the pandemic. This is however without prejudice to the other types of medical treatments, particularly in the context of the legal question of global access under consideration in this article. ${ }^{14}$ Despite the complex and time-consuming process involved, the development of vaccines has made significant progress, essentially more in developed countries such as the USA, UK, Germany, China and Russia, instead of in Africa. Without prejudice to African innovative capacities in research and development, debate among scholars about access, especially concerns for less developed and sub-Saharan countries, has remained dominant in the discussion of the role

12 See AM Stern and H Markel "The history of vaccines and immunisation: Familiar patterns, new challenges" (2005) 24/3 Health Affairs 611 at 612, available at: <https:// pubmed.ncbi.nlm.nih.gov/15886151/> (last accessed 19 August 2021). It has also been claimed that, before Jenner's smallpox vaccine, vaccines can be traced as far back as $1000 \mathrm{CE} / \mathrm{AD}$ to early practices in the treatment of infectious diseases in humans among the people of China, Turkey and Africa, but that active vaccine research and development only emerged much later. See "The history of vaccines: Timeline", available at: <https://www.historyofvaccines.org/timeline/all> (last accessed 19 August 2021).

13 See "Vaccine: Characteristics and types of vaccine", available at: <www.onlinebiologyno tes.com/vaccine-characteristics-and-types-of-vaccine> (last accessed 19 August 2021).

14 In Nigeria and some parts of Africa, herbal preparations from plants such as ginger, garlic, turmeric and lemon have been actively promoted in the fight against COVID-19, although the WHO has cautioned against the use of unproven herbal medicines. A controversial case was the release of an anti-COVID preparation, COVID-Organics or Tambavy, developed by the Madagascar Institute of Applied Research in April 2020. See K Asala "Malagasy Organic COVID-19 capsule cure" (5 October 2020) africanews, available at: <https://www.africanews.com/2020/10/05/malagasy-organic-covid-19-capsulecure//> (last accessed 19 August 2021). The preparation, which claimed it could both prevent and cure COVID-19, was developed in response to the alarming rate of infection in Madagascar, the second highest in the southern African region after South Africa, and was freely distributed in the country. It was also donated to west African countries including Nigeria. See also N Adebowale "Madagascar's 'COVID-19' drug is mainly antimalaria - health minister” (2 July 2020) Premium Times, available at: <allafrica.com/sto ries/202007030140.html> (last accessed 3 September 2021). 
of the patent system in fostering access, as the world has scrambled for essential medicines and vaccines to combat each cycle of the epidemic. ${ }^{15}$

This aptly explains the unfolding position in which the COVID-19 pandemic has placed the global community, particularly in the context of "the all-important vaccine" for the virus. As at April 2020, reports showed over 115 COVID-19 vaccines and treatments under development; ${ }^{16}$ barely five months later, this had grown to more than $150^{17}$ candidate vaccines by top pharmaceutical and research institutions, mostly from the USA, UK, Australia, Russia, Germany and China, which all received substantial funding and were making appreciable progress in the different stages of vaccine development and production in an effort to secure the highest standards of human safety, stability and efficacy obtainable in vaccine technology. ${ }^{18}$ The WHO indicated multi-country "solidarity" clinical trials in order to develop global data and subsequently went further to facilitate global

15 See B Sodipo "Government use of patented medicines in securing access to essential medicines in a post COVID-19 Nigeria” (2020) 42/9 European Intellectual Property Review 603; YA Vawda and B Shozi "Eighteen years after Doha: An analysis of the use of public health TRIPS flexibilities in Africa" (South Centre research paper 103, February 2020). See also O Owoeye Intellectual Property and Access to Medicines in Africa: A Regional Framework for Access (2019, Routledge). See also EFM 't Hoen et al "Medicine procurement and use of flexibilities in the Agreement on TRIPS, 2001-2016" (2018) 96/3 Bulletin of the World Health Organization 185; A Kolawole "Patent rights and essential medicines in developing countries: Is access compromised for innovation in Nigeria?" (2012) 3/3 Journal of Medicine and Medical Sciences 130.

16 Prominent among them were mRNA-1273 (Moderna), Ad5-nCoV (CanSino Biologicals), INO-4800 (Inovio), LV-SMENP-DC and pathogen-specific aAPC (Shenzhen Geno-Immune Medical Institute), Baricitinib (Eli Lilly / Incyte), Kaletra (Eli Lilly), interfero-beta (Eli Lilly) and ritonavir / lopinavir (Abbvie). See also "CEPI publishes analysis of COVID-19 vaccine development landscape”, available at: <www.cepi.net.news_cepi/cepi-publishes-anal ysis-of-covid-19-vaccine-development-landscape> (last accessed 19August 2021).

17 These include: NVX-C0V273 (Novavax), JNJ-78436735 (Johnson \& Johnson), mRNA-1273 (Moderna Therapeutics), BNT162b2 (Pfizer, in collaboration with German BioNTech), Bacillus Calmette - Guerin BRACE (Australia's Murdoch Children's Research Institute), CoronaVac (Sinovac, China), Ads-ncov (Cansino Biologics, China) and Sputnik V (Russia's The Gamaleya National Centre of Epidemiology \& Microbiology). See A McKeever "Here's the latest on COVID-19 vaccines" (3 September 2021, National Geographic), available at: <https://www.nationalgeographic.com/science/article/coronavirus-vaccine-tracker-howthey-work-latest-developments-cvd> (last accessed 3 September 2021).

18 For Oxford's vaccine, see "Five Oxford COVID-19 projects receive UKRI funding", available at: <www.ox.ac.uk/news/2020-04-17-five-oxford-covid-19-projects-receive-ukri-funding> (last accessed 19 August 2021). For Innovio's INO-4800, see "INOVIO expands manufacturing of COVID-19 DNA vaccine INO-4800 with new funding from CEPI" (30 April 2020), available at: <www.prnewswire.com/news-releases/inovio-expands-manufacturing-of-covid19-dna-vaccine-ino-4800-with-new-funding-from-cepi-301049889.html> (last accessed 19 August 2021). See also "Eli Lilly to study Baricitinib for Covid-19 treatment" (13 April 2020), available at: <www.clinicaltrialsarena.com/news/eli-lilly-to-study-baricitinib-for-covid19-treatment/> (last accessed 19 August 2021) for a report of a potential treatment with Baricitinib by Eli Lilly and Incyte using artificial intelligence (BenevolentAI), which was approaching clinical tests. 
distribution. ${ }^{19}$ Since this article was originally written, it must be stated that, in addition to the changing trends and trajectory of the pandemic indicated above, two major developments have taken place: the advent and global distribution of COVID-19 vaccines; and the debate at the World Trade Organization (WTO) concerning the Agreement on Trade-Related Aspects of Intellectual Property Rights Agreement (TRIPS) waiver in respect of the COVID-19 pandemic. ${ }^{20}$ Clearly, these issues are both relevant and valid to the specific issues of compulsory licensing (CL) and government use as the patent law mechanisms for addressing the issue of access examined in this article. With four major COVID-19 vaccines (Oxford/Astra-Zeneca, Pfizer-BioNTech, Moderna and Johnson \& Johnson), the global vaccine distribution landscape has continued to deepen the unfinished discussion of access to pharmaceutical patents under existing global intellectual property (IP) law and policy. Regarding vaccines, pharmaceutical entities as patent holders can ordinarily maintain infringement actions against users, including governments, that lack due authorization or licence and, as the prevailing circumstances have shown, it becomes impossible to achieve affordable and equitable access across the north-south divide. Hence the need to explore alternative options, including the issue of a waiver currently being discussed, which is only recognized in the context of CL and government use and is the focus of this article.

Pharmaceuticals is one of the important industries that rely heavily on IP, essentially in the form of patents. From the stage of formative research to clinical trials to markets, the entire process is conditioned to leveraging on the incentive that innovation brings, with the assurance of overwhelming societal adoption. This lays the ground for the costly tension between the benefits of innovation and the imperatives of access to the products. One of the frameworks of IP law in the form of CL, the subject of this article, provides the balancing mechanism to limit the operation of patents in their fullest extent and help to fulfil the public interest in maintaining access in the innovation market. To this effect, global pharmaceutical and public health industries have come to the full realization of the limit of patents, whether under national law or within the well-known global "flexibilities" framework that seeks to

19 See K Kupferschmidt and J Cohen "WHO launches global megatrial of the four most promising coronavirus treatments” (22 March 2020) Science, available at: <https://www. sciencemag.org/news/2020/03/who-launches-global-megatrial-four-most-promisingcoronavirus-treatments> (last accessed 3 September 2021).

20 The proposal for a TRIPS waiver was first introduced at the TRIPS Council on 15-16 October 2020. See "Waiver from certain provisions of the TRIPS Agreement for the prevention, containment and treatment of COVID-19: Communication from India and South Africa (2 October 2020)" IP/C/W/669, available at: <https://docs.wto.org/dol 2fe/Pages/SS/directdoc.aspx?filename=q:/IP/C/W669.pdf\&Open=True $>$ (last accessed 19 August 2021). The proposal has since been co-sponsored by the delegations from Kenya, Eswatini, Mozambique, Pakistan, Bolivia, Venezuela, Mongolia, Zimbabwe, Egypt, the African Group, the Least Developed Countries Group, the Maldives, Fiji, Namibia, Vanuatu, Indonesia and Jordan. The USA also recently indicated its support for the proposal. 
address broader public health concerns. Therefore, crucially, access to vaccines has important implications for the rationale for and ability of the global IP and public health systems to fulfil the critical objectives of delivering pharmaceutical medicines to the population, especially in sub-Saharan countries like Nigeria that have relatively underdeveloped healthcare and innovation ecosystems.

This article validates the public health expectation implicit in maintaining adequate access to affordable medicines during challenging health emergencies and how the IP system seeks to satisfy that expectation, in situations such as that presented by the COVID-19 pandemic. The article discusses the need to integrate IPRs with public health policies as they relate to access to pharmaceutical patents for COVID-19 related healthcare in Nigeria. In order to meet the public interest objectives under Nigeria's patent law, the article argues the case for adopting government use under the Nigerian Patents and Designs Act (PDA) from various perspectives: a legal and constitutional law perspective of the right to health, and a judicial precedent incorporated into an extant patent law mechanism to strengthen the patent narrative.

\section{INTEGRATING IPRs IN PUBLIC HEALTH: THE COVID-19 PANDEMIC}

In supporting innovation and facilitating access to products of innovation, the role of IP, in particular the patent system, is significant in broad terms, whether at the points of creation, production or distribution, including the question of access to consumers or the public at large. Perhaps more than anything else in global history, public health emergencies have confronted the integrity of the patent system not just in terms of protecting pharmaceuticals themselves but also in terms of access to innovation. IP issues always have an enduring relevance in the entire spectrum of the innovation process. With the advent of successful vaccines arises the issue of access. It is important to note that the public health crises engendered by the COVID-19 pandemic are not limited to fostering innovation in the race for vaccines; the situation also provides the rationale for proactive state institutions, preparing for the challenges that the question of access poses with the arrival of vaccines, to leverage existing IP mechanisms that are specifically designed to address such a scenario. ${ }^{21}$

In the annals of pandemics, the realities of COVID-19 remind the global community of the unfinished IPR-public health debate. Any emergent COVID-19 related patents and technologies should resolve the competing issues of this protracted debate without delay. In the IP-public health dynamic, the question of access is fundamental in both developed, and less developed and developing African countries in ensuring affordable and equitable access

21 See F Gurry "Some considerations on intellectual property, innovation, access and COVID-19” (24 April 2020), available at: <https://www.wipo.int/about-wipo/en/dg_ gurry/news/2020/news_0025.html> (last accessed 19 August 2021). 
to COVID-19 vaccines, particularly in the latter group with relatively weak public health and innovation ecosystems. It is not clear whether or to what extent IP may be a barrier or impact access to COVID-19 vaccines. Nevertheless, concerns and questions of IP protection have engaged the attention of not only vaccine producers and manufacturers, but also the priorities of governments, and health and IP authorities in the progress of vaccine development and production. ${ }^{22}$ This concern is important for good reasons, with at least two being the most germane. First, access to COVID-19 vaccines is already at the centre of two competing forces in the COVID-19 vaccine development landscape: global public and private interest values. On one hand is the global movement for the removal of all obstacles to access, championed by the South Centre, UN General Assembly, WHO, World Bank and others. South Centre, for example, has declared that, "[a]11 COVID-19 related drugs, diagnostics, vaccines and health products, existing and future, should be considered global public goods", further emphasizing that this "will be the only way to make these products available to everyone, everywhere at the same time". ${ }^{23}$ The UN General Assembly has also adopted a resolution to the same effect. ${ }^{24}$ Laudable as these efforts are, on the other hand, the reality does not reflect the shared experience, as the "traditional pharmaceutical business model" has typically always been locked in the competition-monopoly dynamics that are largely driven by the contest over ownership and control of IP rights in the global market. For good measure, IP rights in vaccines and associated technologies are usually the subject of contention among vaccine creators, producers and manufacturers. Even the prospect of a COVID-19 IP pool for all candidate vaccines in order to facilitate faster access did not detract from this reality but in fact provides the rationale behind the multi-country solidarity.

Secondly, concern over the role of IP in facilitating access in the current COVID-19 experience has strong historical roots in the relationship between IP and public health that characterized the debate over the supply of HIV/AIDS drugs. This role speaks to the practical and conceptual bases for balancing patent rights against access to medicines, a subject of significant legal

22 HG Ruse-Khan "Access to COVID-19 treatment and international intellectual property protection - Part I: Patent protection, voluntary access and compulsory licensing” (15 April 2020) 2 European Journal of International Law 30.

23 See "Message from the South Centre to the 73rd World Health Assembly [the WHO's highest decision-making body]" (May 2020), available at: <https://www.southcentre. int/wp-content/uploads/2020/05/WHA-73-Statement-SC-REV1-ENG.pdf> (last accessed 19 August 2021).

24 See UN General Assembly res on "International cooperation to ensure global access to medicines, vaccines and medical equipment to face COVID-19" (adopted 20 April 2020, 74th session, agenda item 123) A/RES/74/274 at 2. See also "COVID-19 response resolution" (19 May 2020, 73rd World Health Assembly, agenda item 3), para 4, recognizing the need for "universal, timely and equitable access to, and fair distribution of, all quality, safe, efficacious and affordable essential health technologies and products, including their components and precursors, that are required in the response to the COVID-19 pandemic as a global priority". 
and policy discourse. ${ }^{25}$ In retrospect, that debate led to the clarification of TRIPS, the Doha Declaration on TRIPS and Public Health (Doha Declaration) in 2001 and the eventual TRIPS amendment, which is still engaging the attention of policy makers and scholars. It is expected that IP lawyers and policymakers across jurisdictions who are familiar with the protracted pharmaceutical patents and public health narratives in the context of access to medicines in HIV/AIDS health emergencies in the 1990s will revisit the lessons from that controversy. ${ }^{26}$ Medical experts would instruct that, in the world of infectious diseases and epidemics that have confronted humanity, state-of-the-art vaccines including the underling manufacturing technologies and associated IP have been the mainstay of global policy responses. COVID-19, regardless of its origin and the conspiracy theories surrounding it, is no exception.

More than two decades after the IP controversy following the HIV/AIDS experience, the COVID-19 pandemic presents another litmus test for the IP system and it is not premature to address this important question in the context of IP systems, as it aligns with wider legal and political systems. Although foreign and humanitarian aid, grants and donations have often helped poorer and low-income countries with the supply of essential medicines, experience has shown that this is not only unsustainable but has also not supported the development of health sectors or the attainment of sustainable development goals in this group of countries. In the bio-medical industries, the prospect of vaccines is almost always present, but places the burden of equitable access on the global community, with a far heavier burden on African and developing, rather than developed, countries. As with previous experience with antiretrovirals, which took years to reach many African countries that were ravaged by HIV, access to COVID-19 vaccines in Africa presents the same sceptre simply because the global pharmaceutical market typically does not serve the public interest in largely low income countries, such as are predominant in Africa. ${ }^{27}$ With the global race for COVID-19 vaccines among the major pharmaceuticals, IP and health policies must therefore recognize the balance between the economic interest of patent holders in the return on their investment in research and development, and the public interest in making the vaccines available at an affordable cost.

25 See CM Ho "A new approach to the compulsory license conundrum" in RL Okediji and MA Bagley (eds) Patent Law in Global Perspective (2014, Oxford University Press) 485 at 489-90, noting that "many nations today provide patents on drugs not because they believe that this will promote greater innovation, but because they are required to under TRIPS".

26 See "IPRs, public health and pharmaceutical industry: Issues in the post-2005 TRIPS agenda" in M Cimoli et al (eds) Intellectual Property Rights, Legal and Economic Challenges for Development (2014, Oxford University Press) 219.

27 See "Urgent medical steps are needed to define how COVID-19 medical tools can really be 'global public goods”' (Médecins Sans Frontières access campaign, 1 May 2020), available at: <https://msfaccess.org/urgent-steps-are-needed-define-how-covid-19-medical-tools-canreally-be-global-public-goods> (last accessed 19 August 2021). 
This balancing question has formed an integral part of the interaction of global patent and public health policies, and the socio-economic analysis of patent protection. Although research and pharmaceutical companies have indicated a willingness to waive or suspend their patent rights in the public interest, the issue of the ability of African and less developed countries to foster access to vaccines without government intervention remains significant. A waiver by itself does not detract from patent protection, except that the patent holder has only decided to waive his right in the patent under justifiable circumstances. There are reports of countries that have adopted a combination of $\mathrm{CL}$ and government use and other extraordinary measures under their respective patent laws in order to make vaccines available to their citizens in the likely event of shortages in global supply. By March 2020 in the raging pandemic, countries including Israel, Germany, France, Chile, Philippines, Australia, Canada and Ecuador had invoked their respective patent statutes or issued special instruments in the form of CL to authorize the supply of COVID-19 vaccines in order to meet current and future exigencies. ${ }^{28}$ Those, essentially non-African, countries positioned themselves to facilitate access to vaccines for their COVID-19 patients and citizens ahead of time. ${ }^{29}$ More countries can be expected to join the CL club in the course of this pandemic in order to satisfy the imperatives of access in the patent-public health dynamic. It is therefore significant to situate the underlying legal and utilitarian value of access to any COVID-19 related vaccines in that context.

\section{PATENT PROTECTION AND PHARMACEUTICALS: COMPULSORY LICENCE FRAMEWORK IN PERSPECTIVE}

Essentially, patents afford the privilege of incentivizing new innovation for the benefit of society. That goal is achieved through the grant of a monopoly for a limited period in order to sustain the engine of innovation that should drive development and economic growth. A country's patent system plays a significant role, both in the progress of innovation and in promoting public welfare through the access it facilitates to useful inventions. Therefore, the essence of a patent as a tool for innovation is only a part of the larger public good. This underlining objective is coterminous to public health objectives and involves

28 Ibid. On 18 March 2020, Israel was reported to be the first country to grant a compulsory licence regarding COVID-19, allowing the import from India of a generic version of Kaletra (an HIV drug) produced by AbbVie to treat COVID-19 for "national defence purposes" under the Israel Patent Act 5727-1976: "Israel issuing compulsory license during the time of COVID-19 pandemic" (IIPRD blog - Intellectual Property Discussions), available at: <https:/iiprd.wordpress.com/2020/04/02/israel-issuing-compulsory-licenseduring-the-time-of-covid-19-pandemic/?utm_source=Mondaq\&utm_medium=syndication \& utm_campaign=LinkedIn-integration> (last accessed 3 September 2021).

29 See "The key COVID-19 compulsory license development so far" (7 April 2020) IAM, available at: <https://www.iam-media.com/coronavirus/the-key-covid-19-compulsory-licens ing-developments-so-far> (last accessed 3 September 2021). 
a complex innovation policy dynamic that supports the public interest. As with the basic requirement under most patent laws, patents in Nigeria are granted under the PDA on every invention, including pharmaceuticals, provided it is new, involves an inventive activity and is capable of industrial application. ${ }^{30}$ This provision is the cornerstone of the patent system, as the exercise of patent rights is dependent upon it. While pharmaceutical companies, as vital parts of a healthcare ecosystem, have traditionally produced drugs for protecting human health, they are commercial entities that utilize the monopoly of patent rights they hold as an incentive that allows them to make a profit on their investment in research and development and to sustain the cycle of innovation. ${ }^{31}$

That universal reality has always raised the concern about maintaining the right balance between the imperatives of private and public interests inherent in the enterprise of promoting public health. This often comes to the fore in emergencies like the current COVID-19 experience, which was desperate for the development of new vaccines that must be paid for in one way or another by the global community. In concrete terms, the most useful way of preventing the abuse of patent rights and also, in the case of pharmaceutical patents, assisting in facilitating access to these drugs, is the framework of CL, broadly defined to include government patent use (public non-commercial use), provided for under most national patent laws as well as under international patent law. This framework reinforces the perspective that the grant of a patent as a property is ultimately subject to limitations or conditions in order to balance the interests of innovators and the public at large. CL essentially serves as a legal tool for government to grant the right to produce or import patented products either directly or through a third party without the authorization of the patent holder. ${ }^{32}$ It is generally regarded as "a proactive government intervention", which seeks to ensure a proper balance in the objectives of rewarding innovation and fostering public welfare. ${ }^{33}$

30 Patents and Designs Act, cap 344, Laws of the Federation of Nigeria (LFN) 2004, sec 1(1). However, patents cannot be validly obtained in two cases: in respect of plant or animal varieties, essentially biological processes or the production of plants or animals (other than microbiological processes and other products); and inventions that would be contrary to public order or morality: id, sec 1(4).

31 For a discussion of the monopoly of patent rights and the pharmaceutical industry in Nigeria, see B Sodipo Piracy and Counterfeiting, GATT, TRIPS and Developing Countries (1997, Kluwer Law International) at 83-118 and 199-201. See also BK Baker "Pharma's seven deadly lies about Thai compulsory licenses" (1 February 2007), available at: <http://www.cptech.org/blogs/ipdisputesinmedicine/2007/02/pharmas-seven-deadlylies-about-thai.html> (last accessed 3 September 2021).

32 See FM Abbott and RV Van Puymbroeck "Compulsory license for public health: A guide and model documents for implementation of Doha Declaration para 6 decision” (2005, World Bank working paper no 61).

33 See C May and SK Sell Intellectual Property Rights: A Critical History (2006, Lynne Rienner Publishers). 
At the international level, TRIPS, which regulates global trade in IPRs, engages this important legal framework or instrument in its functional relevance to national security and public health emergencies. While TRIPS allow patents in all fields of technology, subject to the standard patentability requirements, ${ }^{34}$ it also makes provision for exceptions and limitations to the exclusive rights under patents. In the latter context, CL can be situated in the well-known three-step rule expressed in the overarching provision that limits exclusive rights, in so far as "such exceptions do not unreasonably conflict with a normal exploitation of the patent and do not unreasonably prejudice the legitimate interests of the patent owner, taking account of the legitimate interests of third parties". ${ }^{35}$ Broadly, this has allowed WTO member countries to protect their national security interests or cater for emergencies, as has been demonstrated by the huge impact of the COVID-19 pandemic on the economic, social and political lives of nations. ${ }^{36}$ Although TRIPS, as "a minimum standard" agreement, has witnessed considerable ambivalence both in its rigidities and flexibilities generally and with respect to its relationship with public health (for example, with the Doha Declaration in response to the HIV/AIDS pandemic), ${ }^{37}$ CL has remained the standard legal and policy measure adopted by governments under most patent systems to guarantee access to pharmaceutical patents without the voluntary permission of the patentee. Between the standard guiding patents (including for pharmaceuticals) set out in article 27.1 of TRIPS and its substantive exception clauses, TRIPS has arguably managed to maintain a global patent regime (or imbalance), which has always courted controversy in its application across the global north-south divide. The TRIPS flexibilities construct, therefore, provides the organic framework to bypass exclusive patent rights without risk of infringement and has been utilized to meet diverse public interests, on the grounds of emergency or extreme urgency, anti-competitive practices, public non-commercial use and dependent patents, as determined from time to time by national laws. ${ }^{38}$ One of the key flexibilities available to developing and African

34 See TRIPS, art 27, which provides that patents are available for "any inventions, whether products or processes, in all fields of technology, provided that they are new, involve an inventive step and are capable of industrial application".

35 See id, art 30.

36 See id, art 73(b), which provides that nothing in TRIPS shall be construed "to prevent a member from taking any action which it considers necessary for the protection of its essential security interests". See also, C Correa "COVID-19 pandemic: Access to prevention and treatment is a matter of national and international security" (open letter from executive director of the South Centre, 4 April 2020), available at: <https://www. southcentre.int/wp-content/uploads/2020/04/COVID-19-Open-Letter-REV.pdf> (last accessed 19 August 2021).

37 See Doha Declaration (adopted 14 November 2001), art 4.

38 See TRIPS, art 31. See also Paris Convention for the Protection of Industrial Property (1883), art 52, which can be regarded as the forerunner to TRIPS, art 31. For the arguments over whether or not the grounds are limited to an emergency, see Ho "A new approach", above at note 25 . 
countries under TRIPS pursuant to the Doha Declaration is the right of members to grant $\mathrm{CL}$, with the accompanying freedom to determine the grounds on which this can be granted. ${ }^{39}$ This right is amplified by the right to determine what constitutes a national emergency or extreme urgency with due regard to health crises or particular diseases such as HIV/AIDS, TB, malaria and other epidemics. ${ }^{40}$ Consequently, TRIPS, particularly in the context of the Doha Declaration, has effectively enabled a public health-compliant IP system and provided more fertile grounds for CL since 2001, especially for developing countries. ${ }^{41}$

The well-known concern that CL is more effective in countries that can manufacture drugs locally has been an important consideration in the usefulness of CL, mostly in sub-Saharan countries that predominantly lack sufficient pharmaceutical manufacturing capacity. Evidently Nigeria, which imports a large portion of its pharmaceuticals, satisfies the conditions of a country with low or insufficient manufacturing capacity, low income and a generally weak pharmaceutical infrastructure. This concern reflects the limits of CL to a predominantly domestic market of members authorizing such use, which effectively excludes many least developed and developing countries with poorer domestic manufacturing capacity. ${ }^{42}$ Consequently, the 2005 Protocol Amending TRIPS, made pursuant to paragraph 6 of the Doha Declaration, sought to address this challenge by allowing exports to countries with low manufacturing capacity. This system allows a generic version of patented medicines to be produced under CL exclusively for export to countries that cannot manufacture the needed medicines; this further reinforces TRIPS flexibilities for the benefit of eligible importing countries. ${ }^{43}$ This provision allows the TRIPS Council to assist WTO member countries with insufficient pharmaceutical manufacturing capacity to make effective use of the CL provision. However, giving effect to the TRIPS framework requires compliance and incorporation of the TRIPS provisions into national law.

In this regard, the existing TRIPS flexibilities therefore provide the overarching context in which a waiver has been proposed to suspend the patent

39 Doha Declaration, para 5(b).

40 Id, para 5(c).

41 See also: id, para 5(d); the instruction to the TRIPS Council to find an expeditious solution to the difficulties faced by members with insufficient or no manufacturing capacity in the pharmaceutical sector, in making effective use of the CL provision (id, para 6); and a restatement of the right of least developed countries not to implement the TRIPS provisions in respect to pharmaceuticals until 1 January 2016 and to seek further extensions of this transition period (id, para 7).

42 See TRIPS, art 31(f).

43 The Protocol Amending TRIPS (which will come into force once it has been accepted by two-thirds of WTO members, subject to a deadline of 31 December 2021 or such later date as may be decided by the Ministerial Conference) has been accepted by more than 60\% of members: "Implementation and monitoring" in Annual Report 2016 (WTO), available at: <https://www.wto.org/english/res_e/booksp_e/anrep_e/anrep16_ chap5_e.pdf> (last accessed 3 September 2021). 
protection obligations imposed on WTO member states for at least three years, specifically to meet the primary objectives of preventing, treating or containing the COVID-19 pandemic. While this is an important vista in the whole access debate, it still leaves critical issues, such as the all-important global consensus, attendant economic impact, systemic challenges, including voluntary licensing agreements, technology transfer and manufacturing capacity, relatively open. The two competing positions for and against a waiver have admitted to some of these challenges. ${ }^{44}$ Indeed, what is in contention is not the flexibility afforded under CL and government use that TRIPS allows for generic medicines under domestic law, but its adequacy as a fool-proof solution. Significantly, as a waiver by itself does not guarantee unfettered access, it does not by the same token extinguish the relevance and cogency of the wellknown mechanism of CL and government use, in respect of both the legal and political compromise in the patent system to meet the same objectives of access, albeit without its own hurdles.

On the African continent, the whole idea of TRIPS flexibilities, which provide the premise for $\mathrm{CL}$, has been controversial; nonetheless, they are strategically useful especially with the rising wave of global health crises that led to the Doha Declaration. While the majority of countries on the continent allow patent protection for pharmaceutical products, largely derived from the heritage of colonial IP laws, the existing IP landscape has strived to give credence to the public interest goal of promoting access to pharmaceuticals. This assumption can be supported in at least two essential respects. First, the African IP architecture mostly reflects legislative backing for the use of CL and government use exceptions for patents under existing national and regional frameworks. In varying degrees, this helps to prevent abuses of patent rights and offers an important tool for meeting public health emergencies in different countries in the region. ${ }^{45}$ This is also possible within the context of the two existing regional IP bodies: the African Regional Intellectual Property Organization (ARIPO) for English speaking countries and African Intellectual Property Organization (OAPI) for French speaking countries, which have a combined membership of 41 countries, about 70 per cent of sub-Saharan

44 Notable is the support by a group of academics and experts. See "Academic open letter in support of the TRIPS Intellectual Property Proposal” (LSE Policy Briefing Series, policy briefing 46, July 2021). See also RM Hilty et al "COVID-19 and the role of intellectual property" (position statement, Max Planck Institute for Innovation and Intellectual Property, 7 May 2021); B Mercurio "The IP waiver for COVID-19: Bad policy, bad precedent" (2021) IIC - International Review of Intellectual Property and Competition Law, available at: <https:// doi.org/10.1007/s40319-021-01083-5> (last accessed 19 August 2021); R Thrasher "How will everyone benefit if WTO members sign the TRIPS COVID-19 waiver" (15 February 2021), available at: <www.openaccessgovernment.org/trips-covid-19-waiver/013738> (last accessed 19 August 2021); and Y Vawda "The TRIPS COVID-19 waiver, challenges for Africa and decolonising intellectual property" (South Centre policy brief no 99, August 2021).

45 For example, countries including Ghana, Kenya, Nigeria, Rwanda and South Africa have $\mathrm{CL}$ and government use provisions in their patent laws. 
African countries. ${ }^{46}$ However, with the recent adoption of the Statute of the Pan-African Intellectual Property Organization as a specialized African Union (AU) agency ${ }^{47}$ with functions including harmonizing IP standards that reflect the needs of the $\mathrm{AU}$, its member states and regional economic communities including ARIPO and OAPI, ${ }^{48}$ the prospect of a harmonized and Africa-wide IP system is in the horizon. This prospect is further advanced by the African Continental Free Trade Area Agreement, an important agreement for an African single market and, of course, trade in goods and services involving IP. ${ }^{49}$ The AU has also featured TRIPS flexibilities vis-à-vis the IP laws of African countries in dealing with the HIV, TB and malaria epidemics through the AU Roadmap on Shared Responsibility and Global Solidarity for AIDS, TB and Malaria Response in Africa, adopted in $2012 .{ }^{50}$ Identifying access to medicines as a priority issue, among other areas, the AU enjoined an action to "create a legislative environment that incorporates the full use of the [TRIPS] flexibilities and develops awareness to avoid the incorporation of 'TRIPS-plus' measures in trade agreements" in addressing the epidemic in the region. ${ }^{51}$ This has been significant in the instrumentalization of a patent regime for promoting public health objectives in respect of access to medicines and the momentum of reform on the continent. For example, the emergence of the African Continental Trade Agreement has offered a viable regulatory mechanism that could strengthen the existing low manufacturing capacity of sub-Saharan countries and support the use of a CL regime for the production and distribution of pharmaceutical products in an affordable and equitable manner during public health emergencies and beyond.

Secondly, and consequently, with marked awareness of the impact of patents on access to medicines and legal backing for implementing the flexibilities, coupled with the amendment that is now available to the least developed WTO countries especially for invoking health-related CL, African governments are in a better position to leverage on these flexibilities and

46 The notable exceptions are Nigeria, South Africa and Egypt. See A Adewopo "Trademark systems in Africa: A proposal for the harmonisation of the ARIPO and OAPI agreements on marks" (2003) 6 Journal of World Intellectual Property 473. See also Vawda and Shozi "Eighteen years after Doha", above at note 15 at 27.

47 Adopted at the 26th ordinary session of the AU Assembly, 31 January 2016, Addis Ababa, Ethiopia, art 2.

48 Id, art 4

49 Adopted at the tenth extraordinary summit of the AU Assembly, Kigali, Rwanda, 21 March 2018 (Kigali Declaration). The agreement became effective on 29 April 2019 with 22 countries required for ratification. As at 27 August 2021, 38 of the 55 AU member states had deposited their instrument of ratification: "Status of AfCFTA ratification", available at: <https://www.tralac.org/resources/infographic/13795-status-of-afcftaratification.html> (last accessed 3 September 2021).

50 Available at: <https://apf.francophonie.org/IMG/pdf/annexe_2.pdf> (last accessed 19 August 2021).

51 Id at 3. The other two areas identified in the action plan are diversified financing and enhanced governance. 
advance the use of CL and government use to support the cause of access. ${ }^{52}$ This is despite the well-known challenges regarding lack of pharmaceutical manufacturing capacity and the issue of affordability of patented drugs across countries in the region. At least 17 African countries were reported to have invoked article 31 flexibilities in varying forms on 26 occasions. ${ }^{53}$ For example, the recent issuance of CL by Ghana, Zimbabwe, Mozambique, South Africa, Eritrea, Zambia, Rwanda and Chad, among others, at different times to address their HIV/AIDS related emergencies provides useful precedents in the region. As the COVID-19 pandemic lingers, more uses are expected within the context of TRIPS solutions, as a majority of African countries have not only met the patent protection requirement for pharmaceuticals but would most probably receive a green light to import them in order to maintain access in the face of the supply gap that has attended the release of vaccines. Over 79 million doses of COVID-19 have been shipped to Africa by COVAX, which aims to deliver 521 million by the end of $2021 .^{54}$

\section{A case for government patent use in Nigeria: Legal perspectives}

While the patent system itself has provided the framework for addressing the challenges of access to pharmaceutical medicines, two important approaches or arguments reinforce the broader application of the patent regime and, in this context, the PDA offers significant constitutional and legal rationale for government use as a patent law mechanism for meeting public health emergencies. These arguments, found in extant health law vis-à-vis the constitutional perspective to the right to health and judicial precedent in the application of government use, complement the existing patent law narrative and provide a strong legal foundation for the adoption of a government use regime in Nigeria.

\section{"Right to health" $v$ right to property: Legal and constitutional perspectives}

From a constitutional standpoint, there are two important rights that are implicated in the public interest consideration of government use as a patent

52 This includes countries like Kenya (2017), Liberia (2016), Mozambique (2015), Namibia (2012), São Tomé and Príncipe (2016), Sierra Leone (2012), Seychelles (2014), Uganda (2014) and Zambia (2016), which have revised their respective IP laws since the AU Roadmap was adopted in 2012.

53 See "The TRIPS flexibilities database", available at: < http://tripsflexibilities.medicinesl awandpolicy.org> (last accessed 3 September 2021). The fairly long list includes, for example, the following countries and territories that expressly grant CL and government licences in their respective IP laws: Angola, Botswana, Burundi, Ghana, Liberia, Mozambique, Mauritius, Namibia, Nigeria, Rwanda, Sierra Leone, Sudan, Seychelles, Tanzania, Uganda, Zambia, Zanzibar and Zimbabwe. See also 't Hoen et al "Medicine procurement", above at note 15 at 186 .

54 "COVID-19 vaccine shipments to Africa ramp up" (WHO news and press release, 29 July 2021), available at: <https://reliefweb.int/report/world/covid-19-vaccine-shipmentsafrica-ramp> (last accessed 29 July 2021). 
law mechanism for providing access to essential medicines: the right to health of every person in need of basic medical care and the patentee's IP right or right to property. With respect to the right to health, the power to invoke government use to ensure that needed medicines or vaccines are available to the burgeoning population derives from the exercise of a statutory or executive power under the PDA and equally implies an obligation to implement the legal and constitutional rights in the context of the National Health Act $(\mathrm{NHA})^{55}$ and the Fundamental Objectives and Directive Principles of State Policy (FODPS) under chapter II of the Nigerian Constitution 1999 (the Constitution) respectively. Regarding the NHA, its objectives to "provide for persons living in Nigeria the best possible health services within the limits of available resources" and "protect, promote and fulfil the rights of the people of Nigeria to have access to health care services", among others, ${ }^{56}$ are consistent with a government patent use executive instrument issued under the PDA. There is therefore a significant meeting of objective values. The patent and public health systems fulfil the same objective or, better still, the obligations to ensure access to essential medicines, including the supply of COVID-19 vaccines needed for the "national health system", established by law for the first time in Nigeria. ${ }^{57}$

At the constitutional level, the government use obligation also aligns with the social objectives and obligation of the state to "direct its policy towards ensuring that the health, safety and welfare of all persons in employment are safeguarded and not endangered or abused" and to provide "adequate medical and health facilities for all persons" as an integral part of the FODPS enshrined in the Constitution. ${ }^{58}$ Since the Universal Declaration of Human Rights, ${ }^{59}$ African Charter on Human and Peoples' Rights (African Charter $)^{60}$ and other relevant international instruments, ${ }^{61}$ the right to health has been recognized as one of the components of human rights and has also been recognized in many countries as a legal or constitutional right. In

55 National Health Act, Act No 8, No 145, Vol 101, Government Notice No 208 of 27 October 2014.

56 See id, sec 1.

57 See id, sec 1(1), stating inter alia: "There shall be established for the Federation the National Health System which shall define and provide a framework for standards and regulation of health services".

58 See Constitution, chap II, sec 17(c) and (d).

59 See Universal Declaration of Human Rights, art 25: "Everyone has the right to a standard of living adequate for the health and well-being of himself and of his family including ... medical care ...".

60 See African Charter, art 16: "(1) Every individual shall have the right to enjoy the best state of physical and mental health. (2) State Parties to the present Charter shall take the necessary measures to protect the health of their people and to ensure that they receive medical attention when they are sick".

61 For example, see International Covenant on Economic Social and Cultural Rights, art 12: "... the right of everyone to the enjoyment of the highest attainable standard of physical and mental health". 
Nigeria, when extended to the government use regime, this has the effect of giving the question of access to medicines and healthcare a constitutional or human rights dimension. This is particularly sustained by evolving jurisprudence on the justiciability of chapter II of the Constitution, thereby providing the juridical basis for the right to health as a putative constitutional right, at least potentially. The recent expansion of the frontiers of locus standi by the Supreme Court to give effect to the objectives of "protecting the environment" under chapter II as both a constitutional and statutory obligation lends credence to that assertion. ${ }^{62}$ The court construed the right to a clean environment under section 20 of the Constitution as a human right made enforceable by considerably "liberalizing the rule of locus standi" under section 6(6)(c). ${ }^{63}$ In the landmark decision, Nweze JSC, citing authorities ${ }^{64}$ including in jurisdictions such as India and the UK, ${ }^{65}$ affirmed that, "the proper approach to the interpretation of chap II should be by the mutual conflation of other provisions of the constitution with the provisions of chap II";66 in effect only a narrow reading of the locus standi provision could render chap II of the Constitution non-justiciable. The underpinning principle of this decision can be applied to the sister social objective of "adequate medical and health facilities for all persons" under the same chapter. Thus, it becomes a matter of constitutional right, beyond a statutory right or an obligation activated by an instrument authorizing government use, to provide an adequate supply of medicines in the circumstances of a public health emergency in order to satisfy the public interest and social objectives under the NHA and the Constitution respectively.

Significantly, this perspective reinforces the existing patent law narrative and gives it a stronger legal force, especially in favour of the public health objective of providing access to needed medicines. On the other hand, the

62 See the 2018 decision of the Supreme Court in Centre for Oil Pollution Watch (COPW) v Nigeria National Petroleum Corp (NNPC) suit no SC 319/2013, (2019) (pt 1666) 5 NWLR 518 SC, per Nweze JSC.

$63 \mathrm{Id}$, at 56 and 61 of the judgment.

64 See FRN v Anache; In Re Chief Olafisoye [2004] 14 WRN 63 [2004] (pt 864) 58 per Tobi JSC, holding (at 659): "In my humble view, the non-justiciability of section 6(6)(c) of the Constitution is neither total nor sacrosanct as the subsection provides a leeway by the use of the words 'except as otherwise provided by this Constitution'. This means that, if the Constitution otherwise provides in another section, which makes a section or sections of chap 11 justiciable, it will be so interpreted by the courts".

65 Decisions cited from the UK include: $R v$ Foreign Secretary of State for Foreign and Common Wealth Affairs, Ex Parte World Development Movement Ltd (1995) 1 WLR 386; R $v$ Inspectorate of Pollution and Another, Ex Parte Greenpeace Ltd [No 2] (1994) All ER 329; R v Somerset County Council ARC Southern Ltd, Ex Parte Dixon (1998) Environment LR 111; R v Secretary of State for Foreign and Commonwealth Affairs, Ex Parte World Development Movement Ltd (1995) 1 All ELR 611 at 620 (57 of the Nigerian judgment). Decisions cited from India include: Maharaj Signh $v$ State UP AIR 1976 SC 2607; Raflam Municipal Council v Vardhchard AIR 1980 SC 1622; SP Gupta $v$ Union of India AIR 1982 SC 149 at 189 (55 of the Nigerian judgment).

66 COPW $v$ NNPC, above at note 62 at 57 of the judgment. 
same analogy applies to a patentee's right as a "right to property" construed as such under the Constitution and African Charter and enforceable in Nigeria. ${ }^{67}$ When these rights, namely the right to health and the patentee's right to property, are pitched together, it becomes a question of balancing private rights and the public interest, and the public interest would normally prevail. As Sodipo has argued, correctly, "the patentee cannot use the Constitution to invalidate the government use regime in the PDA as it is a law that is reasonably justifiable in a democratic society in the interest of defence, public safety, public order, public morality or public health". ${ }^{68}$ The constitutional perspective therefore provides a compelling rationale for the performance of government's moral and legal obligations to fulfil the right and to meet critical needs for health and human development. It has also made it even more important to commit significant domestic resources and funding to facilitate access to essential medicines and redress the parlous state of the health sector, which became evident with the outbreak of the pandemic. ${ }^{69}$

\section{Judicial precedent}

It is noteworthy that government use of patents as part of the CL regime is an important part of the history of patent law in Nigeria. Although the introduction of patent law in Nigeria was not particularly intended to foster indigenous inventive activity or local innovation, it took deliberate legislative and judicial interventions to enforce government use as a regulatory measure to preserve government's power to override existing patent rights in the public interest. It can conveniently be posited that government patent use is rooted in judicial decisions before the PDA came into force. The PDA replaced the old

67 By virtue of the African Charter of Human and Peoples' Rights (Ratification and Enforcement) Act, cap A9, 2004 LFN, art 16, which is enforceable in Nigeria and guarantees property rights, expressly including IP rights. Contrast with MCSN v NCC (2008-11) 6 IPLR 72 at 90, holding that IP rights are not the same right to property envisaged under the Constitution, sec 44 .

68 See Sodipo "Government use", above at note 15 at 606.

69 Donations, private and public intervention funds, stimulus packages and palliatives were immediately mobilized to cushion the socio-economic impact of the pandemic. Existing health facilities were rapidly upgraded while new centres and other COVID-19 facilities were hurriedly built across the country. See L Njoku et al 'FG seeks NASS' approval for N500b COVID-19 intervention fund" (5 April 2020) The Guardian, available at: <https://guardian.ng/news/fg-seeks-nass-approval-for-n500b-covid-19-intervention-fund/> (last accessed 19 August 2021). See also C Olisah "How to access the N50 billion CBN COVID-19 intervention fund for SMEs" (1 May 2020) Nairametrics, available at: <https:// nairametrics.com/2020/04/21/how-to-access-the-n50-billion-cbn-covid-19-interventionfund-for-smes/> (last accessed 3 September 2021). The Emergency Economic Stimulus Bill 2020 sought to offer a wide range of measures, including tax rebates, deferral of residential mortgage payments by individual contributors to a national housing scheme for 180 days and waiver of import duties on medical goods. See "House of Representatives passes Emergency Economic Stimulus Bill, 2020” (24 March 2020, Policy and Legal Advocacy Centre), available at: <https://placng.org/i/house-of-representatives-passesemergency-economic-stimulus-bill-2020/> (last accessed 3 September 2021). 
Registration of UK Patent Ordinance of $1925 . .^{70}$ That ordinance only enabled patents granted in the UK to be re-registered in Nigeria after three years of the UK grant, with the effect that the registration in Nigeria only conferred rights and privileges granted by UK law with an extension to Nigeria. ${ }^{71}$

The trilogy of Lodeka cases tested the applicability of government patent use for the supply of pharmaceutical drugs in Nigeria. The first, Rhone SA and May $\mathcal{E}$ Baker $v$ Lodeka Pharmacy, ${ }^{72}$ decided that the provision under section 46 of the UK Patent Act 1949 regarding patent use by the Crown could not apply the whole of the UK act to Nigeria, on the ground that the limitations and obligations imposed on the patentee under that provision did not apply in its entirety to Nigeria. In that case, the British patent was re-registered by the plaintiff in Nigeria after the patent had been originally granted in the UK. The court issued an injunction against the defendant based on the view that the provision for the use of patents in the service of the crown under the UK Patent Act, sought to be incorporated into the PDA, could not apply to avail the defendant.

Following the same trend, the second case, Ciba Ltd $v$ Lodeka Pharmacy Ltd, ${ }^{73}$ arrived at the same conclusion that the same provision of the UK Patent Act, allowing the limitations and obligations imposed on the patentee for the use of the Crown, could not apply as the authority for government patent use in Nigeria in the absence of an express legislative provision that it should so apply. To this extent, government patent use was effectively frustrated by the patentee or the court as the case may be. With the third decision, Wellcome Foundation Ltd $v$ Lodeka Pharmacy, ${ }^{74}$ the situation changed. In that case, the court, for the first time, upheld government use of patented medicine. However, before that decision, recognizing the effect of previous decisions regarding the government's authority to issue exemptions to patents, the then Nigerian military government had passed the Patent Rights (Limitations) Act of 1968, which expressly granted the Nigerian government and agencies powers analogous to the powers allowing the use of patents for the service of the Crown. That was the law under which the third case was decided. Clarifying the distinction between the exemption from liability for infringement and government use of patents under the 1968 law, the court held that, "[r] eading the Decree as a whole, the intention of the legislature is clear that it is desired to give protection to a person who vends a

70 No 6 of 1925, cap 182, 1958 Laws of Nigeria and Lagos. See A Adewopo "According to intellectual property: A pro-development vision of the law and the Nigerian intellectual property law and policy reform in the knowledge era" (2015) Nigeria Institute of Advanced Legal Studies Journal of Intellectual Property 1 at 14.

71 See Registration of United Kingdom Patent Act, 1925, sec 6.

72 [1965] LLR 9.

73 (1968) ALR (Commercial) 352.

74 [1971] All NLR 536; [1917-76] 1 IPLR 219. 
patented article to the government or its agency in the manner which the defendants have done. Such protection from liability for an infringement action will be given on the authority of a Commissioner". ${ }^{75}$

These cases (which were decided under the dependent patent regime under which patents were granted in the UK and re-registered and enforced in Nigeria pursuant to the UK Patents Act) did not settle the applicability of the government use provision of the UK Patent Act in Nigeria. However, three observations are apposite in respect of these cases. First, the cases were decided before the PDA, although the last of them, Wellcome, gave effect to the 1968 law, the position of which on the application of government use was maintained under the PDA. Secondly, they did not exactly involve a public health emergency as a ground for government use, although the authorizations were issued during the period of the Nigerian civil war. Lastly, to that extent, while these cases do not present authorities for government use as is currently permitted under PDA, they provide a historical context for the application of the government patent use regime in the pre-PDA era. With the arrival of the PDA in 1970, government use was firmly established as an integral part of the CL regime. Clearly, the Wellcome decision represents the law on government patent use in Nigeria but, curiously, since then there have been no reported decisions or reports on the use of the government patent use provision, despite different incidences or grounds of public health emergencies in the country requiring the invocation of the provision, including the current COVID-19 pandemic.

\section{STATUTORY / REGULATORY FRAMEWORK: THE PDA IN FOCUS}

As indicated above, the primary legal framework (contained in the first schedule to the PDA) for CL and for the use of patents in the service of government makes extensive provisions regarding the range of circumstances or grounds that may apply in the context of exemptions to existing patent rights. ${ }^{76}$ Fundamentally, CL and government use in particular remain the most practical way of preventing the abuse of patents and providing remedial access in established circumstances of national emergencies. This is the position when the substantive and administrative character of the framework is considered within the context of the enabling provision of the PDA and with due regard to defined emergencies or public interest purposes. In this analysis, the government use provision has been compared with true CL to demonstrate its appropriateness in the current circumstances. Both types of nonvoluntary licences are, as it were, like two sides of the same coin. For this

75 Id at 230, per Dosunmi J.

76 See PDA, first sched, para 11. The first schedule is titled "Compulsory licenses and use of patent for service of government agencies". Part I provides for "Compulsory licences", while part II provides for "Use of patents for service of government agencies". 
reason, it is necessary to set out the grounds for CL under part 1 of the first schedule to the PDA, which cover the following situations:

“(a) that the patented invention, being capable of being worked in Nigeria, has not been worked;

(b) that the existing degree of working of the patented invention in Nigeria does not meet on reasonable terms the demand for the product;

(c) that the working of the patented invention in Nigeria is being hindered or prevented by the importation of the patented article; and

(d) that, by reason of the refusal of the patentee to grant licenses on reasonable terms, the establishment or development of industrial or commercial activities in Nigeria is unfairly and substantially prejudiced."77

Part II of the same schedule provides for the use of patents in the service of government on the following "public interest" grounds:

"During any period of emergency the powers exercisable in relation to a patented article or invention on the authority of a Minister under paragraph 15 of this Schedule shall include power to purchase, make, use, exercise and vend the article or invention for any purpose which appears to the Minister necessary or expedient -

(a) for the efficient prosecution of any war in which the Federal Republic may be engaged; or

(b) for the maintenance of supplies and services essential to the life of the community; or

(c) for securing a sufficiency of supplies and services essential to the wellbeing of the community;

(d) for promoting the productivity of commerce and agriculture; or

(e) for fostering and directing exports and reducing imports (or any class or classes of imports) from all or any countries and for redressing the balance of trade; or

(f) generally for ensuring that the whole resources of the community are available for use, and are used, in a manner best calculated to serve the interests of the community". ${ }^{78}$

These conditions share common characteristics, albeit capturing the relative contexts of emergencies, public interest or exceptional national circumstances. To that extent, they constitute grounds for limiting patents and reflect, in general and specific contexts, extraneous purposes to varying degrees. At least two of the grounds reproduced above directly support the issue of government executive instruments in cases of public health

77 Id, para 1. These grounds are only granted by the court upon application by a person.

78 See id, part II, para 20 (emphasis added). 
emergencies such as the COVID-19 pandemic, which to all intents and purposes constitutes an "emergency" as mentioned, although not defined, in the provision. Indeed, TRIPS itself does not define an "emergency" but gives member states latitude to define what constitutes a national emergency justifying the grant of CL. To that effect, the provision, in broad terms, does not necessarily appear inconsistent with TRIPS. Although CL mechanisms essentially satisfy the same purpose, the two approaches may be different in operation and / or application under different patent systems. ${ }^{79}$ While CL, for example, is subject to a judicial process in some countries, that is not the case with some other patent systems. An application for CL requires a person to apply to the court on the latter of the expiry of four years after a patent application has been filed or three years after the grant of the patent; this suggests that, depending on the applicable ground, it would be necessary to wait four years before applying to the court for $\mathrm{CL}$ in respect of the supply of vaccines in respect of a public health emergency, such as the COVID-19 pandemic. However, this is not the case if the minister issues a government use executive instrument (for public non-commercial use). ${ }^{80}$ In public health emergencies, it would be inconceivable to take the longer route of a court-ordered CL instead of using the more expeditious government use executive instrument. In this situation, the pharmaceutical industry might deliberately use both the waiting period and the slow court system to frustrate the CL regime or for the relevant minister not to issue a compulsory licence for the supply of essential medicines in a prevailing emergency.

Within the purview of the freedom granted to member states to determine the grounds for CL, the question arises whether the PDA complies with TRIPS in respect of its CL framework, particularly given the two applicable approaches and the governmental body involved as the issuing authority: in the case of government patent use, an executive instrument; and / or in the case of true CL, a judicial or court order based on the requirement for an application to the court. In the former case, an executive instrument authorizing government use is issued by the relevant minister for public non-commercial use of a patent without any recourse to the court or judicial process, unless the order is challenged by the patentee. ${ }^{81}$ In the case of $\mathrm{CL}$, the judicial order is issued at the instance of the licensee, permitting commercial

79 See A Adewopo "Public health, access to medicines and the role of patent system in Nigeria" (2011) 1 Nigerian Institute of Advanced Legal Studies Journal of Intellectual Property 164.

80 See PDA, first sched, part II, para 19, stating that government use takes precedence over any subsisting agreement, assignment or licence, as the case may be and accordingly any such instrument "shall be of no effect" as regards the use of the product covered under the CL authorized by the government.

81 See id, para 17: "Paragraphs 15 and 16 of this Schedule shall have effect so as to exempt (a) the Government; (b) any person authorised under those paragraphs; (c) any supplier of the Government or of any such person; and (d) any agent of any such supplier, from liability for the infringement of any patent relating to the relevant article or invention 
exploitation of the patented product. In effect, the government use approach saves time in two essential respects: there is no reference to the courts and it is not subject to the delays that are characteristic of the judicial process in Nigeria. In serving a common and overarching public interest objective, while the grounds are broader with CL than for government use, the issuing authority is different, although both are organs of government. To that extent, the distinction between CL and government use is more procedural and structural than substantive. As indicated above, the nature and scope of the grounds are sufficiently broad for the purposes of promoting and protecting public health in the period of a national emergency engendered in a pandemic, particularly with government patent use where the relevant minister, when satisfied that it is in public interest and without reference to the courts, can authorize any person to supply the patented product for the service of government or its agencies. ${ }^{82}$

It could be argued that, to the extent that it grants the minister blanket powers to issue a government use authorization without prior negotiation with the patent-holder once the minister is "satisfied that it is in the public interest to do so", the provision is at variance with the TRIPS requirement for negotiation. ${ }^{83}$ However, this is attenuated by the requirement that prior negotiation may be waived in the case of national emergency, which WTO member states reserve the right to determine. ${ }^{84}$ The period of emergency is defined as any period of emergency howsoever declared or notified by or on behalf of government, be it state or federal or their respective agencies. The fact that classical CL is granted by a court implies that it may be subject to the delays associated with the judicial process, as noted above. From the practical standpoint of patent law, the ample ease of administration afforded in the powers and process of government patent use under the PDA is vital to the effort for promoting access to affordable COVID-19 vaccines without delay. In the convergence between the Nigerian patent and public health policies and regulatory systems, government use can therefore be better suited to guarantee access to COVID-19 vaccines.

contd

and from liability to make any payment to the patentee by way of royalty or otherwise" (emphasis added).

82 It is important to note that government use may be authorized before or after the relevant patent has been granted, or before or after the doing of the acts in respect of which the authority is given (in other words potentially having retroactive effect); and whether or not the patentee is authorized directly or indirectly to make, use, exercise or vend the relevant article or invention.

83 See PDA, first sched, para 15: "Notwithstanding anything in this Act, where a Minister is satisfied that it is in the public interest to do so, he may authorize any person to purchase, make, exercise or vend any patented article for the service of a government agency in the Federal Republic" (emphasis added).

See Doha Declaration, para 5(c). 
It is instructive to note that, within the PDA framework, unlike CL, which expressly excludes import, government patent use does not entirely prohibit importation. This bears upon the construction of the ground of "fostering and directing exports and reducing imports (or any class or classes of imports) from all or any countries and for redressing the balance of trade". ${ }^{85}$ In strict economic terms, issuing government patent use authorization for the purpose of the import of essential medicines or vaccines in a pandemic should not by itself be construed as inconsistent with the imperative of "reducing imports" or "redressing the balance of trade", at least to the extent that such imports meet the TRIPS requirement for countries to take advantage of article 31 of TRIPS. This distinction is important in the light of TRIPS vis-à-vis the power to invoke relevant government use provisions in order to allow local production and / or the import of drugs during the period of the emergency, where the whole set of circumstances (for example, production costs, local manufacturing and technological capacity and overall socio-economic conditions) are important conditions for taking the necessary steps to make life-saving drugs available to the public. Indeed, within the context of the rights of member states, public health crises such as HIV/AIDS, TB, malaria and others (including the current COVID-19 pandemic) "can represent a national emergency or other circumstances of extreme urgency" that requires the import of medicines. ${ }^{86}$ The TRIPS CL framework is generally understood for what it is: a framework for standard patent limitation and to meet the flexibility needs of WTO member states (especially least developed and developing countries) to fill the gaps or deficiencies in their respective local manufacturing capacities for the supply of essential medicines. Therefore, compliance should not be viewed too narrowly, rather broadly and liberally in order not to defeat the objectives. In the present circumstances, the issue of a government use executive instrument to authorize access to medicines, presents an important legal and policy option available to health policymakers to ensure a prompt and adequate supply of COVID-19 vaccines for the welfare of millions of Nigerians over time. As the "most comprehensive non-voluntary licence", 87 it is advised that the Nigerian government, perhaps for the first time in the history of public health emergencies, considers the adoption of a government patent use executive instrument available under the PDA for the supply of COVID-19 vaccines to Nigerians. The pandemic has awakened countries to the need for a swift and effective response by utilizing available pre-emptory and extraordinary legal, regulatory and administrative measures, such as government use, for importing effective vaccines. ${ }^{88}$

85 PDA, first sched, part II, para 20(e).

86 Ibid.

87 See J Kuanpoth Patent Rights in Pharmaceuticals in Developing Countries: Major Challenges for the Future (2010, Edward Edgar Publishing) at 34.

88 For example, it is reported that the president of Ukraine offered USD 1 million to any scientist in the country who developed a COVID-19 vaccine: "Ukraine president offers $\$ 1$ 
Government use under the PDA provides the minimum legal requirement for meeting the country's need for adequate and sustainable access to medicines and vaccines during national emergencies. While admitting the potential role of a waiver, it is perhaps important to appreciate that there is substance in the position that, viewed in context, waiver and government use are not mutually exclusive, and play complementary roles in the enterprise of maintaining some measure of equitable global distribution. ${ }^{89}$

In that respect, both federal and state governments are urged to issue appropriate executive instruments pursuant to the enabling provisions of the PDA for the use of patents for the service of government agencies for the "maintenance" and "sufficiency" of "supplies and services" "essential to the life and wellbeing of the community" for the supply of approved COVID-19 vaccines in Nigeria. ${ }^{90}$ This would help to guarantee the supply of needed vaccines and drugs for Nigerians, given the apparent lack of manufacturing capacity and affordability for patented medicines, thereby safeguarding public health in this challenging time. The concurrence of patents (as a federal matter in the exclusive legislative list) and health (in the concurrent list in the legislative competence of both federal and state governments) is reinforced by the PDA, which expressly confers the power to make relevant regulation for CL and government use for emergencies, among other purposes, on both federal and state governments and their agencies. ${ }^{91}$

\section{CONCLUSION}

In the context of the current global health emergency engendered by COVID-19 on the public health system, this article has examined the role of patent law in meeting public health objectives, referencing African countries and Nigeria in particular. In view of the global race for COVID-19 vaccines and the anticipated shortage in supply, the article recommends the adoption of government patent use executive instruments as a viable patent law mechanism for making COVID-19 vaccines available to over 200 million Nigerians and by extension over 1.3 billion people in Africa who are potentially in need of

contd

million for COVID-19 vaccine" (13 April 2020) Channels Television, available at: <https:// www.channelstv.com/2020/04/13/ukraine-president-offers-1-million-for-covid-19-vaccine/> (last accessed 3 September 2021).

89 M Eccleston-Turner and M Rourke "The TRIPS waiver is necessary, but it alone is not enough to solve equitable access to COVID-19 vaccines" (2021) 25/9 American Society of International Law Newsletter 1.

90 The recommended regulation under the title: COVID-19 (Compulsory Licenses and Use of Patents for Service of Government Agencies) Regulation 2020 (Patents and Designs Act, 1970, can be issued under the power and authority of the president and respective state governors.

91 See PDA, first sched, sec 23, stating that government agencies include voluntary agencies and hospitals wholly or partly maintained by the government by way of grant aid or otherwise. 
the vaccine. Extending government use beyond the traditional patent narrative, the article adopts the legal and constitutional right to health, supported by judicial authorities, to reinforce the rational basis for government use in the current COVID-19 public health crisis. This measure has become necessary to consolidate the legal, economic and moral rationale for the government's interventions, including appropriate funding to save millions of lives that may be lost where vaccines are not available or affordable to the Nigerian public.

In conclusion, it is important to note that an indigenous innovative role in bio-medical research and the development space as an important contribution to the global search for COVID-19 vaccines is a laudable and realizable vision. This can be achieved by mustering political and deliberate implementation of existing national research and development policies, a collaborative effort of Nigerian universities, research institutes, scientists (both foreignbased and local) and a range of partnerships, incorporating and encouraging proven traditional knowledge-based therapies and treatment regimes to join global vaccine development. There is no doubt that this requires considerable funding and investment. With the wave of economic downturns that the pandemic has engendered globally, the customary inflow of aid and global funding, on which countries in the region have historically relied from donor institutions and development partners, may no longer offer a readily available and sustainable option for the supply of COVID-19 vaccines to the burgeoning population. The current landscape is characterized by solidarity and cooperation, largely driven by the WHO's COVAX partnership with developed countries to shore up global vaccine supply, particularly for developing and African countries. In light of this, the right to CL and government use as part of the framework of flexibility under TRIPS to give full effect to allowing low-cost generic vaccines to be produced remains valid, and the objectives of access to vaccines can be significantly enhanced for the benefit of the global community during and after the pandemic. For example, Nigeria has so far received nearly 8 million doses of COVID-19 vaccines from both COVAX and the USA, with more expected. ${ }^{92}$ There is no gainsaying that appropriate

92 On 2 March 2021, Nigeria received 3.94 million doses of AstraZeneca vaccines shipped by COVAX, a partnership between the WHO, CEPI, GAVI and UNICEF: "COVID-19 vaccines shipped by COVAX arrive in Nigeria” (2 March 2021, WHO), available at: <https://www. afro.who.int/news/covid-19-vaccines-shipped-covax-arrive-nigeria> (last accessed 19 August 2021). Similarly, on 4 August, Nigeria received another 4 million doses of Moderna vaccines shipped by the US government: P Adepoju "US donation enables new Nigerian rollout where only 0,6\% are vaccinated against COVID” (4 August 2021) Health Policy Watch, available at: <https:/healthpolicy-watch.news/nigeria-steps-tovaccinate-more-of-its-211-million-people/> (last accessed 19 August 2021). More supplies are reportedly expected from COVAX and the US government: C Ohuocha "Nigeria expects nearly $8 \mathrm{mln}$ more COVID-19 vaccines by end August - official", available at: <https://www.reuters.com/world/africa/nigeria-expects-nearly-8-mln-more-covid-19vaccines-by-end-august-official-2021-07-13/> (last accessed 3 September 2021). 
implementation of the PDA government use regime, as a beneficial IPR licensing regime and strategic regulatory measure, supported by TRIPS flexibilities, would enhance the supply of generic vaccines and assist in meeting the potential demand in Nigeria. This would serve as a good opportunity not only for dealing with the challenge of access to COVID-19 vaccines, but for offering the first real test for government patent use in Nigeria since the PDA came into force 50 years ago.

\section{CONFLICTS OF INTEREST}

None 